\title{
FREEDOM OF SPEECH AS A FUNDAMENTAL RIGHT WITHIN THE SITUATIONAL CONTEXT OF THE REPUBLIC OF MOLDOVA AND TRANSNISTRIA
}

\author{
Marin DOMENTE \\ Doctor of Law, University of European Political and Economic Studies „Constantin Stere”, \\ Chisinau, Republic of Moldova \\ e-mail:domente.marin@gmail.com \\ https://orcid.org/0000-0002-7572-5271
}

\begin{abstract}
The right to freedom of expression and information is guaranteed by Article 10 of the European Convention for the Protection of Human Rights and Fundamental Freedoms (ECHR) in all member states of the Council of Europe. The case law of the European Court of Human Rights (ECHR) applying Article 10 must be considered an international standard of authority on the protection of this human right, including the right to express, transmit and receive opinions and information without the interference of public authorities. Freedom of expression is one of the most cherished constitutional rights in democracies. Freedom of expression affects every aspect of our social and political system and receives explicit and implicit protection in every modern democratic constitution. Moreover, it is frequently mentioned in public discourse and has inspired an impressive volume of legal and philosophical literature. Since its inclusion in Article 19 of the Universal Declaration of Human Rights, the right to freedom of opinion and expression has been protected in all relevant international human rights treaties. In international law, the freedom to express opinions and ideas is considered essential both at the individual level, insofar as it contributes to the full development of a person, and being a cornerstone of a democratic society.
\end{abstract}

Keywords: freedom of speech, constitutional freedom, fundamental right, Republic of Moldova, Transnistria.

\section{LIBERTATEA DE EXPRIMARE CA DREPT FUNDAMENTAL ÎN CONTEXTUL SITUAȚIONAL AL REPUBLICII MOLDOVA ȘI TRANSNISTRIA}

Dreptul la libertatea de exprimare și informare este garantat de articolul10 din Convenția europeană pentru protecția drepturilor omului și a libertăților fundamentale (CEDO) in toate statele membre ale Consiliului Europei. Jurisprudența Curții Europene a Drepturilor Omului (CEDO), care aplică articolul 10, trebuie considerată un standard internațional de autoritate cu privire la protecția acestui drept al omului, inclusiv dreptul de a exprima, transmite și primi opinii și informații fără interferența autorităților publice. Libertatea de exprimare se numără printre cele mai prețite drepturi constituționale din democrații.Libertatea de exprimare atinge fiecare aspect al sistemului nostru social și politic și primește protecție explicită și implicită în fiecare constituție democratică modernă. Mai mult, este frecvent menționată în discursul public și a inspirat un volum impunător de literatură juridică și filosofică. De la includerea sa în articolul 19 din Declarația universală a drepturilor omului, dreptul la libertatea de opinie și de exprimare a fost protejat in toate tratatele internationale relevante privind drepturile omului. În dreptul internațional, libertatea de a exprima opinii și idei este considerată esențială atât la nivel individual, în măsura în care contribuie la dezvoltarea deplină a unei persoane și fiind o piatră de temelie a societății democratice.

Cuvinte-cheie: libertate de exprimare, libertate constituțională, drept fundamental, Republica Moldova, Transnistria. 


\section{LA LIBERTÉ D'EXPRESSION EN TANT QUE DROIT FONDAMENTAL DANS LE CONTEXTE SITUATIONNEL DE LA RÉPUBLIQUE DE MOLDOVA ET DE LA TRANSNISTRIE}

Le droit à la liberté d'expression et d'information est garanti par l'article 10 de la Convention européenne de sauvegarde des droits de l'homme et des libertés fondamentales (CEDH) dans tous les états membres du Conseil de l'Europe. La jurisprudence de la Cour Européenne des Droits de l'Homme $(C E D H)$, appliquantl'article 10, doit être considérée comme une norme internationale d'autoritéence qui concerne la protection de ce droit de l'homme, y compris le droit d'exprimer, de transmettre et de recevoir des opinions et des informations sans ingérence des autorités publiques. La liberté d'expression est l'un des droits constitutionnels les plus chers dans les démocraties.

La liberté d'expression touche tous les aspects de notre système social et politique et bénéficie d'une protection explicite et implicite dans toute constitution démocratique moderne. De plus, il est fréquemment mentionné dans le discours public et a inspiré un volume imposant de littérature juridique et philosophique. Depuis son inclusion dans l'article 19 de la Déclaration universelle des droits de l'homme, le droit à la liberté d'opinion et d'expression est protégé dans tous les traités internationaux pertinents relatifs aux droits de l'homme. En droit international, la liberté d'exprimer des opinions et des idées est considérée comme essentielle à la fois au niveau individuel, dans la mesure où elle contribue au plein développement d'une personne et constitue une pierre angulaire de la société démocratique.

Mots-clés: liberté d'expression, liberté constitutionnelle, droit fondamental, République de Moldova, Transnistrie.

\section{СВОБОДА СЛОВА КАК ФУНДАМЕНТАЛЬНОЕ ПРАВО В СИТУАЦИОННОМ КОНТЕКСТЕ РЕСПУБЛИКИ МОЛДОВА И ПРИДНЕСТРОВЬЯ}

Право на свободу выражения мнений и информации гарантируется статьей 10 Европейской конвенции о защите прав человека и основных свобод (ЕКПЧ) во всех государствах-членах Совета Европы. Прецедентное право Европейского суда по правам человека (ЕСПЧ), применяющее статью 10, должно рассматриваться как международный стандарт власти в области защиты этого права человека, включая право выражать, передавать и получать мнения и информацию без вмешательства государственных органов. Свобода выражения мнения - одно из наиболее важных конституционных прав в демократических странах. Свобода выражения мнения влияет на все аспекты нашей сочиальной и политической системы и получает прямую и косвенную защичту в каждой современной демократической конституции. Более того, она часто упоминается в публичном дискурсе и послужила вдохновением для создания внушительного объема правовой и философской литературы. С момента включения в статью 19 Всеобщей декларачии прав человека право на свободу мнений и их свободное выражение защищается во всех соответствуюших международных договорах по правам человека. В международном праве свобода выражения мнений и идей считается важной как на индивидуальном уровне, поскольку она способствует полному развитию человека, так и является краеугольным камнем демократического общества.

Ключевые слова: свобода слова, конституционная свобода, основные права, Республика Молдова, Приднестровье.

\section{The actuality and importance of the theme}

Constitutional democracy is a way of organizing relations between government and individuals inside national states. It is essentially characterized by the acceptance of a written or unwritten constitution that performs as a higher law and guarantees even against governmental powers certain human rights that, according to historical and rational agreement, people may never be deprived of, such as life, freedom, property, equality, due process and vote. Freedom of speech is probably the brightest star in the constellation of constitutional rights.

In a first approach, freedom of speech could be defined as a principle according to which individuals must have the liberty to hold and express ideas through oral language and writ- 
ing, symbolic gestures or images, in any platform and concerning a variety of matters, from politics to religion, economy to history, without fearing or suffering censorship or punishment. However, despite of what this broad concept might suggest, freedom of speech is not conceived anywhere as a right that grants protection to everything that can be uttered. In free speech legal doctrine, for instance, "the most stringent protection of free speech would not protect a man in falsely shouting fire in a theatre and causing a panic". This old sentence expresses a view that remains as one of the most powerful in free speech thinking and ruling everywhere: freedom of speech is limited; it does not cover all kinds of speech.

The right to freeexpressionis one of the main fundamental human rights. Consecrated in the Constitution of the Republic of Moldova, it explains on the one hand the importance of application as a mean of guaranteeing the expression of opinion and involvement of civil society in the legal evolution of the state, and on the other hand evokes the qualitative expression of defending citizens' rights and freedoms.

The actuality of the approached subject also lies in the fact that by constitutionalizing the right to freeexpression, at least two main goals are achieved: firstly, the right of citizens to freely express their personal opinions is guaranteed;secondly, the citizen who resorts to this possibility, is protected by the constitutional norm, against any acts of persecution, sanctioning and punishment for his opinions expressed according to the law.

Free speech is commonly thought to promote democracy. Democracy rests on the principle of self-government, whereby political decisions ultimately belong to citizens either directly or through representatives. In the logic of the system, freedom of speech fulfills central functions, such as allowing voters to make informed choices in elections. Also, thanks to freedom of speech, people can influence public policies, and authorities are subject to criticism that may lead to their replacement. Abuse of power and corruption can be denounced and maybe prevented by fear of revelation. Beyond that, conflicting interests in the community are identified and accommodated in favor of social stability, and individuals and minorities that openly dissent may relieve frustrations and do not need to use violence as an alternative to get power, to fight government programs or to gain attention for reformist claims. Finally, better political deliberations should be taken with the audience of all sides of debate.

The normative regulations, of the studies in the field and of the incomplete fundamental comparative analyzes confer an even more serious connotation on the researched issue, as the institution of the right to free expression presupposes one of the few means of defending the citizens against state abuses. Defective application of legal provisions in this regard affects the interest of society as a whole.

Taking into account the citizen's involvement in the decision-making process through the right to free expression, we express our belief that at the moment the issue of studying and ensuring the free expression of opinion is of unquestionable actuality because:

- we are in a process of transition to democracy, which shows that we are barely learning what democracy is, which implicitly involves ensuring the realization of the right to free expression;

- the mechanism for realizing the right to free expression is in continuous formation with the involvement of new circumstances due to the evolution of social life.

- the legal regulation and the realization of the right to free expression require a permanent analysis both of the legal framework in the matter and of the practical activity of the authorities in order to assess its efficiency and the responsibility with which it is respected;

- the situation of power in the state and the decrease of the citizen's trust in the state authorities became more and more accentuated, 
moment that emphasizes more and more the need of viable solutions for the consolidation of the trust and of the constructive dialogue between these subjects.

Taking into account the stated moments, we consider that the scientific investigation of this subject is fully current, in order to elucidate the solutions likely to strengthen the role of the right to petition for the development of democracy.

Destined for the multifaceted research of the right to free expression from the definition of philosophical concepts to the forms of realization it covers in all social relations, there is also the need to substantiate unique concepts of the institution of the right to free expression, with the possibility of correct application. material law through those of formal law.

The actualityof the paper derives from the fact that in the field literature, it will bring its additional contribution through the legal approaches performed, so it is a paper following the implementation of scientific syntheses, research, able to result in clear concepts, rules, procedures, implementation based on strict observance of legal provisions.

Scientific research methodology. The process of investigating issues related to the constitutional guarantees of freedom of expression is based on the study of theoretical, normativelegislative doctrinal material, the jurisdictional experience of the ECHR, as well as the Republic of Moldova.

Regarding the methodological and theoretical-scientific support of the paper, it manifests different research methods, such as:

a) the logical method that represents different arguments on the deductive way;

b) the comparative method, extremely useful in comparing the acts that regulate and guarantee the freedom of expression of opinion;

c) the historical method based on revealing the meaning of past events;

d) the sociological method that includes different sociological instruments; e) the quantitative method that contributes to the systematization and legislative evidence, storage and systematization of legal scientific information.

Using the methods highlighted above, it was possible to study and analyze the whole complex of issues related to the international and national regulations of the current constitutional of the Republic of Moldova on the right to freedom of opinion and expression.

Freedom of speech is among the most cherished constitutional rights in liberal democracies. It is entrenched in most contemporary constitutions as well as in international human rights treaties. It is often classified as a "first generation right" - a right protecting individuals from interference by the state. It is understood to be foundational to liberal policies either in the sense that it is a precondition to the existence of a liberal policy and/or that it is tightly related to liberal values such as autonomy, dignity and liberty. At the same time, the scope of what constitutes speech, what speech ought to be protected, the weight or the value attributed to the protection of speech vis-à-vis other rights or policy concerns, and the reasons underlying its protection are highly controversial. These controversies have important political and legal implications and they are reflected in the differential protection granted to speech in different jurisdictions. [5]

\section{Freedom of speech, case of the Republic of Moldova and Transnistria}

The primary philosophical challenge is to explain why (and whether) speech ought to be protected more (or differently) than non-speech activities. When we protect speech we privilege speech relative to non-speech activities. The normative debate concerning the justifications for protecting speech also sheds light on what counts as speech. Only communicative action that at least potentially promotes the values underlying the protection of speech counts as speech. Consequently, identifying the values 
underlying the protection of speech also influences what activities count as "speech." Thus, at least in legal discourse, the question of what counts as speech and what counts as protected speech are often interrelated. To address the normative question of why speech is protected as well as to identify what counts as speech we examine below.[5]

The scope of what the right to free speech includes is of course controversial. Often the scope of what constitutes "speech" is influenced by normative considerations. Yet, it is evident that the term "speech" is much too narrow to describe all the activities that are traditionally covered by the right to free speech. As Schauer noted: "What is 'speech' in ordinary usage isnot necessarily what is 'speech' for purposes of the concept of free speech" [7]. Waving a flag, wearing a button with political symbols and producing a movie are also protected by the right to free speech. In contrast, there are activities that are clearly speech (in the ordinary sense of the word) that are not protected by the right to free speech, such as hiring somebody to commit murder. Often the right to free speech protects communicative activity - namely activity that conveys ideas, expresses emotions or sentiments, or conveys or evinces attitudes. Yet not all communicative activity is protected; physically attacking a person as an expression of hatred is not covered by the right to free speech even if it is a communicative activity.

The special protection of speech is part of a more general phenomenon characterizing many rights; rights protect certain forms of behavior, e.g., speech, religion, equality, etc. They provide, therefore, differential protection to different activities. One of the great challenges of a theory of rights in general and a theory justifying the protection of any particular right is to explain the reasons underlying the differential protection of activities, all of which seem to produce similar benefits and generate similar harms. In the context of speech, we can ask why should speech and non-speech activities which are equally autonomy enhancing (or, more generally, equally value enhancing) be protected differentially [4]?

Among the classical justifications for free speech is the claim that free speech is a prerequisite for democracy. As the very concept of democracy is controversial, it is to be expected that there are several different democracy-based arguments for free speech. Is democracy valuable as a procedural method on grounds of fairness or equality? Or is it based on the greater likelihood of desirable decisions to emerge from a democratic process? If it is the former, the desirability of free speech need not hinge on its quality or its expected consequences. If it is the latter, then what counts is rational or deliberative participation (that is more likely to result in good or desirable decisions) and the scope of the protection of speech ought to reflect this concern.

In order to develop democracy pluralistic state has to provide an overview of the principles on the basis of which it develops diverse options and program policy of governing the country, to organize activities transparent to government and to all public authorities, found its embodiment in expressing the diversity of conceptions and opinions that are interposed between the individual and the state in the relations that take place between the members of the society and various state and non- state institutions [8, p.37 ].

Ensuring pluralism in all species it's in particular pluralism political, is regulated by multiple documents and instruments international because at base basis philosophy of pluralism it is the very idea of freedom of the individual in the sense politically. With the freedom policy in her company pluralistic citizen continues to be manifest as in -a framework pluralistic institutionalized state [2, p.26].

Being the center of numerous controversies and debates at level national and international, both from the perspective of theoretical, but 
also practical, theme achievement freely the right to express freely the opinion, presents a real interest, individually and collectively, create a framework generous the discussion also involves the need to clarify the report with other rights or interests fundamental belonging authorities national or individuals [6, p.44].

Freedom of expression of opinion is a right integrator, a right generator, which generates and other rights and freedoms are inextricably linked with each other and there only in whole. In this sense, are the relevant statements of Frederic Sudre who believes that freedom of expression of opinion is both a right in itself and an as indispensable or injurious to the realization of other rights (freedom of speech is indispensable freedom of assembly, but may bring prejudice to the right to life private); both a right individual that takes the freedom spirit of each person, and a law convivial, allowing communication with others [8, p. 351].

The subjective right is the prerogative, conferred by law in virtue of which the holder of the right can and sometimes even must, to carry out a certain conduct and to ask others conduct a conduct proper law of his, under the sanction provided by law, in order to capitalize the interest staff directly, born and actual, legitimate and legally protected, the agreement with interest general and the rules of social coexistence [3, p.136].

Article 8 of the Constitution of the Republic of Moldova sets available through which undertakes to comply strictly and in good faith the obligations that in return the treaties to which it is part, and regulation of constitutional of Article 32 guarantees all member states the right to free expression of opinion.

Limits the exercise of the right to freedom of opinion and expression specifying -the fact well known that any right ends there where begin the rights of others. We attribute this sentence full legal quality, because, really, every holder of rights and freedoms has obligations, both in terms of legal, and morally to exercise rights in such a way that it should not to affect the rights and freedoms of others. Being disseminated in the public, it is normal that freedom of expression should be subject to some limitations of the freedoms of others and the needs of defense of the public interest [3, p. 24].

Organizing policy of any social human community gives rise to a complex variety of relationships between governors and the governed, to which regulation by rules has as objective to ensure a harmonization of interests, specific to different socio-professional categories, and exclusion ofpotential conflicts generated by the violation of rights and legitimate interests of citizens. No society can claim that has not failed to totally meet the full requirements of group or personal interests of people and to prevent abuses of the public administration, violation of rights and legitimate interests of citizens protected by law. This is the reason for which constitutions establishe, in general, access to free justice and the right of any person aggrieved by an authority public to address court, to have their recognized rights violations by public government, or the right of citizens the address petitions topublic authorities [1, p.121].

In terms of realization and application of law mentioned we present and analyze the latest developments of this right both in the Republic of Moldova, as and in Transnistria.

\section{Case study Transnistria}

Authorities closely monitor and control the public media, and Sheriff Enterprises dominates private broadcasting, leading to widespread self-censorship. The territory's few independent print outlets have limited circulation. Critical reporting can result in reprisals including criminal charges, and the government also uses bureaucratic obstruction and withholding of information to inhibit independent journalism.[10]

Legislation adopted in 2016 gave authorities even greater control over state media outlets, 
including the power to appoint editorial staff, and enabled officials to limit media access to their activities and bar the use of recording devices.[10]

Travel restrictions related to COVID-19 further limited access to the territory for Moldovan and foreign journalists during 2020. Separately, telecommunications regulators in January suspended the license of LinkService, a smaller competitor of Transnistria's leading internet service provider, which is owned by Sheriff Enterprises. An appellate court blocked the decision in April and allowed LinkService to continue operating at least through the end of the public health emergency.[10]

Legal restrictions on certain kinds of speech discourage free discussion. Among other provisions related to defamation or insult of the authorities, the criminal code penalizes public expression of disrespect for the Russian peacekeeping mission.[10]

Speech-related prosecutions of dissidents, activists, and ordinary social media users have become more common in recent years, inhibiting expression by other residents. In addition to the cases against Communist Party politicians during 2020, a criminal investigation regarding incitement to extremism was opened in March against Larisa Kalik, who had recently published a book documenting abusive conditions in the Transnistrian military. She fled the territory as a result. Also in March, it was reported that pensioner Tatiana Belova and her husband, SergheiMirovici, had been sentenced to three years in prison for "extremism" and "insulting the president" via posts on Telegram in 2019. Belova was released in July, but Mirovici reportedly remained in prison.[10]

\section{Case study Republic of Moldova}

The media environment is dominated by outlets connected to political parties. With few exceptions, nationally broadcasting television stations are owned by people affiliated with political parties. Reporters have previously faced difficulty accessing publicly important information and threats of legal action from public figures and politicians.[9]

Journalists were also affected by the government's COVID-19 response. In March 2020, the Moldovan media regulator attempted to restrict outlets from quoting unofficial sources, before rescinding that decision a day later. Journalists also faced longer waits for the fulfillment of access-to-information requests due to COVID19-related policy changes.[9]

There is a good degree of academic freedom in Moldova. However, the Orthodox Church strongly indoctrinates the Moldovan educational system, with educational officials at all levels frequently promoting the church and Orthodox beliefs.[9]

Individuals have generally been able to engage in discussions of political nature without fear of retribution. However, under the PDM's rule, there were credible concerns that criticizing the government or affiliated actors could lead to damaged career prospects. Private discussion was curtailed by surveillance against the opposition, journalists, and civil society actors. However, these fears subsided after the 2019 fall of the PDM government.[9]

\section{Conclusions}

Mass communication became particularly of importance in politics and business to governments and society, due to the possibilities offered, to inform and influence people, which has caused a certain blurring of forms of traditional ways of communication. Political parties, especially those who are in government, but also those in opposition, sre always in competition of disinformation, manipulation of opinion by creating opinions favorable to work their interests or ideology on which they promote. Misinformation must be banned and sanctioned.

Developing ofmodern technology in the means of communication made the society to confront with issues of regulatory policies 
particularly complex ones, in connection with written media, with broadcasting and television which are of nature to exert a great influence on public opinion. Thus, misuse can bring to significant harm to the rights and freedoms of the individual, as well as conduct the bases of democratic public life.

The information, in some cases, infringes honor, dignity and reputation of professional, and may be distorted by the critics, by manipulating opinion, by misinformation, by hiding the truth, through surveys of opinions or even by silence. Such a situation should be banned and imposed sanctions by standards legislation.

The right to free expression is the main topic discussed in many works of local as and foreign scientists which is represented as a mean of preventing an injustice.

In connection with democracy, freedom of speech tends only to justify the coverage of ideas and messages with political content or interacting in the political process. So, if democracy was the only basis for protecting freedom of speech, things like self-help literature, commercial advertising, sports journalism and entertainment magazines would be left out of perspective. More important: the same could happen with allegedly defamatory or invasive statements. Probably, these types of speech would be understood as not belonging to the constitutional worries, and in this case, greater or lesser freedom related to them would then depend on the legislative power. But this is not how things are: freedom of speech is valued for reasons other than democracy, and then, it justifies much more than just political messages.

\section{Bibliography}

1. ANDREESCU, G. Comentarii la Constituţia României, cu un studiu introductiv de Bogdan Iancu. Iaşi: Polirom, 2010. 279 p.

2. BORDEI, Lilia, Principiile democrației pluraliste în activitatea parlamentară, Chișinău: 2010. $139 \mathrm{p}$.

3. DELEANU, Ion. Drept constitutional și instituții politice, Vol. II, Fundația "Chemarea", Iași:, 1993. p. 250.

4. HAREL, A. "Theories of Rights" in M. P. Golding and W. A. Edmundson, eds., The Blackwell Guide to Philosophy of Law and Legal Theory, Malden, Mass.: Blackwell Publishing, pp. 191-206.

5. HAREL, A., Freedom of Speech (September 21, 2011). COMPANION TO PHILOSOPHY OF LAW, Andrei Marmor, ed, Routledge, Forthcoming, Available at SSRN: https://ssrn.com/ abstract $=1931709$

6. MOLDOVAN, Carmen. Libertatea de exprimare. Principii, restricții, jurisprudență, București: Ed.C.H. Beck, 2012. 249 p.

7. SCHAUER, F. (1982) Free Speech: A Philosophical Enquiry, Cambridge: Cambridge University Press

8. Sudre Frederic. Drepteuropeanşiinternaţional al drepturiloromului, Polirom, București, 2005. $353 \mathrm{p}$.

9. https://freedomhouse.org/country/moldova/ freedom-world/2021

10. https://freedomhouse.org/country/transnistria/freedom-world/2021 